\title{
Examining the Impact of Socio-economic Dimensions of Capitalism on Global Security and Sustainable Development: A Strategy for Poverty Eradication towards Sustainable Development
}

\author{
Michael O. Mojekeh \\ Department of Marketing, Anambra State University, Nigeria
}

Copyright $(2016$ by authors, all rights reserved. Authors agree that this article remains permanently open access under the terms of the Creative Commons Attribution License 4.0 International License

\begin{abstract}
Any decision on sustainable economic development, must address three fundamental questions, which among others include what has been happening to poverty; unemployment and inequality or economic injustice. If all these three variables have declined from high levels, then there has been a period of development in the affected country. A descriptive approach was adopted from secondary source of data. Today we are witnessing a growing precarious economic situation of glaring distortion, disequilibrium and disharmony globally. Neo-liberal capitalism promotes individualism, greed, self-interest, primitive accumulation and economism - (which regard human societies primarily, as economic systems in which financial considerations alone, govern choices and decisions). Other fundamental values, such as faith spirituality, justice, love, compassion, sympathy, empathy and co-operation, are unwittingly neglected. This paper examined and highlighted the impact of socio-economic dimensions of capitalism on sustainable development and proffers avenues for realistic and sustainable socio-economic stability and peace. Cognizance of the above facts, the recommendations among others, are that the economies and societies around the world, should be encouraged to promote and connect economic efficiency with economic ethics and justice. This entails that the curricula of Business Schools, Universities and other Higher Institutions, must contain both the doctrines of capitalist ideology and true human values of morality and spirituality, for the world to enjoy global peace, security and sustainable development. Also, to build an "Economy of Communion" for the "Common Good of all", which signifies not just a clarion call for less inequality but also, for more fairness and economic justice for the ultimate good of all. If the "Economy of Communion" is established and adopted, one would be inclined to believe, that it will go a long way in eradicating "Corporate Greed" and exploitation, which will culminate into discouraging the likes of Occupy the Wall Street Movement" that keeps reverberating all over
\end{abstract}

the world.

Keywords Capitalism, Economic Justice, Poverty, Socio-economic Dimensions, Sustainable Development

\section{Introduction}

The prevailing and fast-growing global economic crises, shockwaves, disturbances, and insecurity, are not really unconnected with the economic system that is generally acceptable to various economies and societies around the world-the Western capitalism. It is pertinent to note that in the beginning, it was not so, but the greed-motivated, selfish economic growth and corporate bottom-line conscious minority of the world, who are unwittingly, the unchallenged beneficiaries of this economic system, at the detriment of the already exploited and impoverished majority of the world population, have bluntly refused to accept this unassailable fact and change the prevailing precarious economic situation globally.

Today, the world is inundated with such phrases as: "Economic Meltdown", "Financial Downturn", "Bank Distress and Failure", "Plummeted Stock Market", "Global Shockwaves", :Global Financial Tsunami", National Financial Tsunami", "Eurozone Debt Crises", "Corporate Greed. Economic Inequality and Hunger in Nigeria/USA", "Sex Tourism, Human Trafficking and the 21st Century Slavery", "Revolution in Egypt", "Battle For Libya", "Protesters Crackdown in Syria and Yemen", "Protesters /Doctors Imprisonment in Bahrain", "Humiliation, Dehumanization and Exploitation of Gold/Copper Miners in Indonesia and Argentina", 'Protest Against Government Cutbacks, Corruption Scandal in the World Football Governing Body FIFA - 2015-2016 (on-going), and Corporate Greed taking place across the World, inspired by 
"Occupy Wall Street" movement New York in USA; Tokyo, Japan; Philippines: Taipei; Taiwan; Sydney; Australia: London: Hong-Kong; Manila Berlin: Dublin and still spreading all over the world, even to Africa-Niger Delta Militants (South-South), Boko Haram in (North east/Central), Kidnapping (South East) CNN and Aljazera Global News, 2011-2015). The complexity of these problems is climax and by certain remarks of the IMF-Chief Christine Largarde on various occasions, without proffering any realistic solution: "the global economy has entered a dangerous phase" (Largarde, September 2011). The global economy is entering double-dip recession (Largarde, 2011). The world economic outlook has worsened in the last three weeks (in October) (Largarde, 2011).

"The world cannot get out of its current state of crisis with the same thinking that got it there in the first place" (Albert Einstein). Without proper definition of the cause of the problem, the solution will continue to be elusive.

\section{Objectives of Study}

The broad objective of this paper is to examine the genesis and the impact of the socio-economic dimensions of capitalism and to proffer avenues for realistic and sustainable global economic balance and peace.

\section{Conceptual Framework}

Ironically, we tend to forget that from the beginning of creation, all the gifts are from God. I mean everything that exists, including the earth, the planets, the stars (constellation/galaxy), the land, the air, the sea, the sun and all the vital natural resources, such as water, oil, gas and coal, were all created for the benefit of all God's creation. It can be argued that all our most important natural and economic resources, owe nothing to human labour and procedure, and nothing to the economic variables and postulations. Regrettably, in the human race today, the modern economic theory, with our materialistic disposition, laid much emphasis on wealth creation, without the creator of the whole universe. Today, the genuine relationship between the creator and the creation is dislocated and destroyed. Man has sidelined the Omnipotent, Omnipresent and the Omniscience, that knows the end from the beginning, and created, enthroned and worshipped the god of mammon, in the application of western capitalism. In the beginning, it was not so, and this may not be unconnected to the global upheavals and insecurity. Examples are the corporate greed and Niger-Delta militants in Nigeria. In the old African setting, especially the Igbo extraction, water the free gift from God, is given free to your neighbours, even to your enemies. Today, those who diverted and converted public funds, amassed wealth through profiteering among others, can dig boreholes in their neighbourhood, only to start selling this free gift from God, at a high rate, to the already exploited and impoverished neighbours, even in the rural settings.

\section{Western Capitalism: What is it all about?}

The Western Capitalism is characterized by individualism, greed, self-interest, primitive accumulation and economism (which regard human societies primarily as economic systems in which financial considerations alone govern choices and decisions). Other fundamental values such as faith, spirituality, justice, Love, compassion, sympathy, empathy and cooperation are neglected Mofid, [5]. The greed, individualism and self-centeredness, deeply embedded in neo-liberalism/western capitalism, runs contrary to the core principles of democracy, community and society. Basically, democracy believes in equality: it gives one vote to each person regardless of status, colour or creed, and irrespective of whether that person is intelligent and educated or illiterate, well-informed or not, physically challenged or disabled.

Western capitalism aims to reward only the most talented and successful, thereby promoting the superiority of individual preference of the minority and at the detriment of the majority. Albeit, their overall notion is that those who squander their riches in conspicuous consumerism are justified, and are as worthy as those who use their wealth to help the needy, the downtrodden and the exploited Mofid [5].This is a Clear negation of the most fundamental principle of democracy, and it is the crux of the matter. The marketplace is not just an economic sphere, "it is a region of the human spirit". Granted that self-interest is an important source of human motivation, driving the decisions we make in the marketplace every day, those decisions nevertheless, have a moral, ethical and spiritual content, because each decision we make, affects not only ourselves but others too Mofid [5].

Today, we have modified and still modifying nature - (the material of the universe), to create wealth so that our ultimate desire to acquire wealth and happiness may be satisfied. Tragically, man has turned the masterpieces of material science, into the engines of destruction, which is threatening to annihilate the civilization, which produced them. This is a challenging, delicate and sensitive situation that calls for urgent solution with two options: Find the light of the truth in the government of our personal/corporate relationships, one with another, or submit willingly to the consequences of our ignorance of the two forces at work in society, the material and the spiritual forces.

Today, a situation of disequilibrium and disharmony is very glaring in our country and globally invariably, only the re-awakening of the human spirit of love, justice and compassion, will save us from our own impending worse extremes of socio-economic dimension of capitalism. The physical wealth accumulation must move in tandem with spiritual, moral and ethical wealth. 
The main global socio-economic problems faced by the modern world are: abject poverty, greed, monumental corruption in Nigeria, U.S.A, Europe and most recently the corruption scandal in FIFA, injustice, exploitation, aids, inequality, starvation, famine, mistrust, child/drug and alcoholic abuses, crime, spin, marginalization, fear, exclusion, sleaze, sex tourism, anxiety, loneliness, Intolerance, Despotism, dictatorship, 21st century slavery: human trafficking, xenophobia and environmental pollution, degradation, exploitation, destruction, and sit-tight public officers/executives (30 years someone is still in office occupy one position). Evidence abound that western capitalism has failed the world, For instance, the recent scandals that involved multinationals and national corporations, such as Enron, World.com, Xerox, Tyco, Dynergy, Arthur Anderson, Global Crossing, Adelphia, and AOL, Oceanic Bank, NNPC, Intercontinental Bank, Premier Breweries, Orient Bank. Cadbury Nigeria Plc, NITEL, Nigerian Stock Exchange, over N20 billion Pensioners' Fund diverted and converted by Pension Department Officer, amongst others, can attest to this colossal failure. These big corporations nose-dived to a new level of disgraceful recklessness and irresponsibility through financial re-engineering, insider abuses, fraud and false accounting. The greed-motivated capitalist economy is spinning out of control through fraud and corruption, dishonesty fueled by personal/corporate greed. Today, what matters most to the shrewd capitalists, are economic growth, the corporate bottom line and the pursuit of self-interest with impunity, at the detriment of others (majority), For example, bank failures in Nigeria, just like in most countries, resulted to silent death of the "voiceless, hapless and helpless (majority). Ultimately, all true happiness and virtue in this world comes from selflessness and generosity, all sorrow from egoism, selfishness, greed and primitive accumulation. We must get beyond greed, selfish individualism and primitive accumulation, in order to achieve realistic and sustainable global socio-economic balance and peace and development.

\section{The Concept of Poverty and the Poor}

It is an irony that Nigeria with abundant resources (human and natural) has been stagnated in its first forty years as a nation with 2.85 GDP growths in the 1990 s. $54 \%$ poverty level, $8 \%$ unemployment level, high level of corruption, second country with the highest maternal death rate, HIV/AIDS prevalence rate of 5.15 and collapse of the education sector Soludo [7].A classical definition of poverty sees it as "the inability to attain a minimal standard of living" measured in terms of basic consumption needs or the income required for satisfying them World Bank [11].Poverty is thus characterized by the failure of individuals, households, or entire communities to command sufficient resources to satisfy their basic needs. However, the World Bank [11] World Bank Development Report defines poverty as "an unacceptable deprivation in human well being that can comprise both physiological and social deprivation". Physiological deprivation involves the non-fulfillment of basic material or biological needs, including inadequate nutrition, health, education and shelter. Social deprivation widens the concept of deprivation to include risk, vulnerability, lack of autonomy, powerlessness and lack of self-respect. Poverty as portrayed in the above definitions has many dimensions, such as inadequate access to basic things of life, malnutrition, lack of access to social services and lack of social and political status. Poverty means lack of command over basic consumption needs Ravallion \& Bidani [6].However, Englama \& Bamidele [2]. Aptly summarized the definition of poverty in both absolute and relative terms, as a

"state 'where an individual is not able to cater adequately for his/her basic needs of food, clothing and shelter, meet social and economic obligations; lacks gainful employment, skills, assets and self esteem; and has limited access to social and economic infrastructure such as education, health, portable water and sanitation, and as a result has limited chance of advancing his/her capabilities.

Poverty, therefore, is a pronounced deprivation in well-being.

Individuals who are victims of poverty are usually referred to as poor while nations suffering from it are called poor nations. Globally, there are so many poor people and poor nations with the attendant continuous social unrest, disturbances and political upheavals. The end is not really in sight, until there is a modification or even outright change of the prevailing economic system.

Nigerians rank low, in terms of access to electricity, safe drinking water and adequate housing. They also suffer from insufficient calorific intake (Uniamikigbo, [10]. The characteristics of the poor and vulnerable in Nigeria include: members of female headed household, the abandonee old or elderly, with no relatives to support them, the displaced children and street children, the refugees resulting from tribal crisis and their hosts, the redundant and retrenched civil servants, pensioners, unemployed graduates, the members of large families and polygamous households, the migrating cattle Fulanis as well as Almajiris and street urchins in Northern Nigeria, the Niger Delta Militants and the Boko-Haram in the North.

\section{Development}

Development here connotes an attack on deprivation, and the meeting of basic human needs such as adequate nutrition, safe water, education, medical facilities and services, transportation and shelter which are all the components of poverty definition. It also includes a feeling of self worth on the part of Nigerian citizens Uniaikigbo [10].

Development economists see development as a multi-dimensional process, involving changes in structures, 
attitudes and institutions, as well as, the acceleration of economic growth, and all encompassing prism or perspective of overcoming and eradicating persistent poverty, diseases, ignorance, unemployment, environmental degradation, etc .Based on the fact that development process is multifaceted, it demands the use of multiple tools, disciplines and strategies which the past Nigerian Poverty Alleviation Policy makers seen to know but effective implementation has always been elusive. Francis [3].says that development is a process that is aimed at improving the living conditions and circumstances of human beings in all ramifications; hence, for meaningful development to take place there must be development in the social, economic, political and cultural aspects of the society. Sustainable development is "development which meets the needs of the present generation without compromising the ability of the future generations to meet their own needs United Nations [9].

\section{Poverty Alleviation Programmes / Institutions and Agencies}

Poverty is a global phenomenon, which threatens the survival of mankind. This informed the United Nations to declare 1996 as the "International Year for the Eradication of Poverty" and October $17^{\text {th }}$, of every year designated as the "International Day for the Eradication of Poverty" Worldwide. Similarly, the decade (1997-2000) has been declared United Nations "Decade for Eradication of Poverty". The concern over increasing poverty levels especially in the developing countries and the need for its alleviation as a means of improving the (standard of living of the people has led to the conceptualization, design and implementation of various poverty alleviation programmes worldwide. This is based on the universally recognized position that no meaningful progress in terms or growth and development can be achieved in a country with predominantly poor population.

The term "poverty alleviation programme" is almost a household phrase in Nigeria. It refers to the various measures, policies, programmes and projects, which the Federal, States, and Local governments, as well as non- governmental organizations (NGOs), have put in place to reduce the incidence of poverty in the country. CBN (2003) indicate that, the philosophy behind these poverty alleviation programme and projects is based on the commonly accepted socio-economic profiles that about 20 percent of Nigerians live below the poverty line. The task is mainly to ensure that most, if not all Nigerians arc provided with;

- Steady source of income

- High purchasing power

- Abundant, good quality and high nutritional rood

- Basic health care facilities

- Good quality education

- Good quality drinking water

- Good standard housing units

- Stable and affordable power supply

- Good urban and rural communication facilities

- Cheap and affordable consumer products, and
- Conducive environment for production and trade.

In order to achieve the above tasks, therefore, the government established the under listed programmes and projects that directly or indirectly were targeted at reducing poverty as shown in table 1 below:

Table 1. Selected Federal Government Programmes and Projects on Poverty Alleviation

\begin{tabular}{|c|c|}
\hline A & 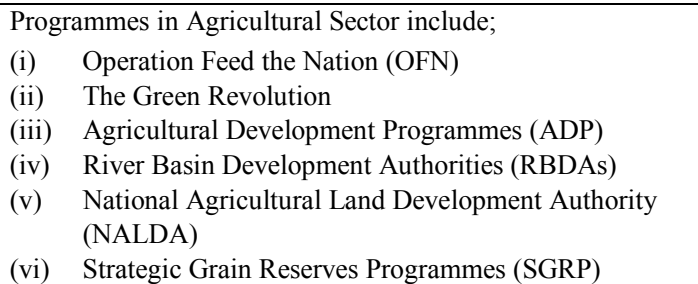 \\
\hline B & $\begin{array}{l}\text { Health Sector; } \\
\text { (i) Primary Health Care Scheme } \\
\text { (ii) Guinea Worn Eradication Programme } \\
\text { (iii) Expanded Programme on Immunization } \\
\text { (iv) Roll Back Malaria. } \\
\end{array}$ \\
\hline $\mathrm{C}$ &  \\
\hline $\mathrm{D}$ & $\begin{array}{l}\text { Transport Sector; } \\
\text { (i) Urban Mass Transit Programmes } \\
\text { (ii) Federal Assisted Mass Transit Programme } \\
\end{array}$ \\
\hline E & $\begin{array}{l}\text { Housing Sector; } \\
\text { (i) Low-Cost Housing Programme } \\
\text { (ii) National Housing Fund Scheme } \\
\end{array}$ \\
\hline $\mathrm{F}$ & \begin{tabular}{ll}
\multicolumn{2}{l}{ Finance Sector; } \\
(i) & Rural Banking Scheme \\
(ii) & National Agricultural Insurance Scheme (NAIC) \\
(iii) & National Economic Reconstruction Fund (NERFUND) \\
(iv) & Peoples Bank of Nigeria \\
(v) & Community Bank \\
(vi) & Nigeria Agricultural and Rural Development Bank \\
& (NACRDB) \\
(vii) & Petroleum Special Trust Fund (PSTF) \\
(viii) & Nigeria Industrial Development Bank (NIDB)
\end{tabular} \\
\hline $\mathrm{G}$ & $\begin{array}{l}\text { Manufacturing Sector; } \\
\text { (i) Small-Scale Enterprise Scheme } \\
\text { (ii) National Directorate of Employment (NDE) }\end{array}$ \\
\hline $\mathrm{H}$ &  \\
\hline
\end{tabular}

Source: Compiled from the Field Survey in the Related Government Ministries, 2015.

It is evident from the above presentation that the Nigerian government has instituted many programmes and projects aimed at poverty reduction. It is equally glaring that many ministries and agencies have taken part in executing poverty alleviation programmes and project in the country. However, despite all these, the results are not as resound as expected. And the major executors of these programmes and projects 
are the Ministries at both federal and state levels, whose activities are relevant to poverty reduction, as well as, International Donor Agencies and Non- Governmental Organizations (NGOs) that provide resources and technical assistance as shown in table 2 .

Table 2. Some of the Ministries and Agencies that Facilitate Poverty Alleviation in Nigeria

\begin{tabular}{|l|ll|}
\hline A & \multicolumn{2}{|l|}{ Ministries } \\
& (i) & Federal Ministry of Agriculture and Rural Development \\
& (ii) & Federal Ministry of Health \\
& (iii) & Federal Ministry of Education \\
& (iv) & Federal Ministry of Transport \\
(v) & Federal Ministry of Works and I lousing \\
(vi) & Federal Ministry of Finance \\
(vii) & Federal Ministry of Industry \\
(viii) & Federal Ministry of Science of Technology \\
(ix) & Federal Ministry of Water Resources \\
(x) & Federal Ministry of Power and Steel \\
& (xi) & Federal Ministry of Petroleum Resources \\
& (xii) & Federal Ministry of Environment \\
& (xiii) & Federal Ministry of Information \\
& (xiv) & Federal Ministry of Women Affairs and Youth \\
& & Development \\
& (xv) & Federal Ministry of Solid Mineral Development \\
\hline
\end{tabular}

Source: Compiled from the Field Survey in the Related Government Ministries, 2015.

\section{Theoretical Perspective}

There is urgent need for us to order the modern world, so that we may all live well and live in peace, according to God's original master-plan for mankind. The clarion call reveals that modern globalized culture desperately needs conscience, morality, ethics, spirituality and faith. Mofid [4].argued that it is only by bringing together the common beliefs within our religious traditions and applying them to our economic systems, that we can create an all- inclusive world for the common good of all. Below are extracts of the views of great thinkers and scholars about western capitalism.

- "A nation that continues year after year to spend more money on military defense, than on programmes of social uplift, is approaching spiritual death" (Martin Luther King)Jnr.

- "There is at the core of the celebration of markets, relentless tautology. If we begin by assuming that nearly everything can be understood as a market and that markets optimize outcomes, then everything leads back to the same marketize! If in the event, a particular market does not optimize, there is only one possible conclusion: it must be insufficiently market-like" (Robert Kuttner).

- "This focus on money and power may do wonders in the market-place, but it creates a tremendous crisis in our society. People, who have spent all day learning how to sell themselves and to manipulate others, are in no position to form lasting friendships or intimate relationships... Many Americans hunger for a different kind of society, one based on principles of caring, ethical and spiritual sensitivity, and communal solidarity. Their need for meaning is just as intense as, their need for economic security" (Rabbi Michael Lerner).

- $\quad$ The only possible alternative to being the oppressed or the oppressor is voluntary cooperation for the greatest good of all" (Errico Maletesa).

- "The public resources go to the rich. The poor, if they can survive in the labour market, fine. Otherwise, they die, that is economics in a nutshell" (Noam Chomsky).

- "The purpose of economic theory is to make those who are comfortable feel comfortable" (Lord Balogh). For example, economic bailout for Greece, AMCON for Banks and over N22billion unclaimed dividends in NSE - all geared to propagating and recycling poverty and impoverishing voiceless and helpless investors and nobody is talking.

- "From the point of view of economy, the sale of weapon is indistinguishable from the sale of food. When a building collapses, or a plane crashes, it's rather inconvenient from the point of view of those inside, but it is altogether convenient for the growth of the gross national product, which sometimes ought to be called the "gross criminal product" (Eduardo Galeano).

- "It is difficult to get a man to understand something when his salary depends upon his not understanding it" (Upton Sinclair) -- "Occupy Wall Street" Movement, Syria, Libya, Egypt, Boko Haram Riot in Brazil(June, 2013) etc.

- $\quad$ "So long as all the increased wealth modern progress brings, goes but to build up great fortunes, to increase luxury and make sharper, the contrast between the "House of Have" and the "House of Want", progress is not real and cannot be permanent" (Henry George).

- "A reasonable estimate of economic organization, must allow for the fact that unless industry is to be paralyzed by recurrent revolts on the part of outraged human nature, it must satisfy criteria that are not purely economic" (R.H. Tawney).

- "I confess that I am not charmed with the ideal of life, held out by those who think that the normal state of human being, is that of struggling to get on; that the trampling, crushing, elbowing and treading on each other's heels, which form the existing type of social life, are the most desirable lot of human beings (John Stuart Mill).

Injustice describes the presence of obvious or hidden disparities among individuals. These disparities can include discrimination in terms of wealth opportunities, resources, services, benefits, decision-making, status, power and influence.

\section{Envisioning the Way Forward}




\section{Promoting Economic Justice}

Ethics and justice-based capitalism is the indispensable panacea for socio-economic stability, peace and development for the common good of all. Leon Maclaren observed that justice is deemed a hallmark of modern civilized societies, while injustice and its effect are visible globally. He classified justice into political or civil justice and economic justice. Regrettably, of the curricula of virtually all Business Schools, Departments of Economics, Faculties of Medicine, Pharmaceutical Sciences and Management Sciences, in our universities, are spiritually impoverished. If our students are taught only the capitalist ideology, divorced from spirituality, from respect for a power greater than them, then we cannot blame them if they go on to mismanage the Oceanic Banks. Intercontinental Bank Plc, Orient Bank Ltd. Premier Breweries and Enron's of this world: convert, divert and embezzle public funds as Governors, Speakers, Senate Presidents, Ministers, Council Members of higher institutions and executive officers, in Banks, NSE, SEC and Oil Subsidy Fraud. For a more ethical world to be realizable, the education of our future leaders, must be more holistic because there can be no civilized marketplace without morality and spirituality. The global economies and societies must get beyond the prevailing unbridled greed and selfish individualism and inculcate the true human values, such as justice, love, sympathy and cooperation.

Many of the disgraced chief executives of American companies received their MBAs from Harvard University: Enron, Worldcom and Arthur Anderson. In Nigeria, many politicians/businessmen who destroyed the economy of their States and Nigeria graduated from OAU, UNILAG, UNN, and ABU. "Love of God can increase only when selfishness is reduced. If one could ultimately get rid of selfishness, one will be at perfect peace whose world and pleasure is the will and pleasure of God. It is only by seeing other people and things as God's creation, created in his own image, that we will stop abusing and exploiting them for our own ends" Mofid [4].

Ironically, our secular society has alienated itself from its spiritual roots, through greed and selfish mentality, the bane of sustainable development of a truly human existence.

God's vision for humanity is a level playing field for all, not survival of the fittest or wealth for the fittest alone, the law of animal jungle-"might is right". Our Universities' Economics Departments, and Business Schools, are made barren wastelands, spiritually arid places; because they have failed to connect economic efficiency and economic justice.

\section{Everyone Should Have a Stake in Society}

Well-being or wholeness is achieved in many religions through healing of mind, body and spirit. Wholeness means eternal (inner) peace, a sense of contentment and cooperation. It involves being in harmony with ourselves, with those around us, our neighbours and with God.

Conversely, the western capitalism encourages us to inculcate individualism, selfishness, consumerism, profit maximization, greed and primitive accumulation. It teaches us that the world is fiercely competitive, that the market makes the final decision. In the beginning, it was not so. Unbridled greed and individualism, and nurture and escalate crime wave and insecurity with the attendant rise in "Gated Accommodation" especially in Nigeria. After amassing wealth through exploitation, profiteering, conversion, diversion and embezzlement of public funds and financial re-engineering, the rich live in isolation behind bars, fearing for their property and even for their lives. Unfortunately, the desire of the rich to find a small "gated" area in which they feel secure, only expands the vast areas in which they feel insecure ... In other words, as people feel safer behind "gated" accommodation, their fear of the outside world increases. In other words, "this voluntary exclusion is mirrored by the involuntary isolation from society, of those trapped in the ghettos of the socially excluded" the armed robbers, kidnappers, prostitutes and rebels/protesters in Libya, Boko Haram, Niger Delta Militants, MASSOB in Nigeria, Syria, Yemen, Bahram etc. Mofid [4].added that from gated communities, we move inexorably to gated countries - our prisons are full, our borders fortified, our embassies armed: our national, regional and global summits, take place behind cordons of riot police and even council meetings in higher institutions.

Invariably, it is only by addressing the root causes of insecurity, namely - poverty, unemployment, inequality, exclusion and exploitation that security can be achieved globally, especially in Nigeria. Good People of God, we need strong iron bridges, not "gates" of brass and bars of iron. Granted that market creates wealth and jobs, - plenty of money but not for all. It does not create well-being, nor happiness and nor contentment. It brings about fierce competition, which creates insecurity. Ironically, jobs may be created in one region or country (China, Korea, Taiwan, Nigeria), but at the expense of another (USA, Japan, Britain, France), and production will move to places where the workforce can be most exploited (Nigeria, Korea, China, Taiwan).

Western capitalism brought about such terminology as Downsizing and restructuring (the poor getting poorer), takeovers (Access Bank Plc took-over Intercontinental Bank $\mathrm{Plc}$, at a ridiculous price-tag (owners/shareholders impoverished); Assets of Oceanic Bank that worth billions taken over by AMCON, but nothing for the shareholders/stakeholders - economic injustice, deregulation and privatization, can nurture the greediest business practices "The Gales of Creative Destruction", Deregulated markets make money (the removal of oil subsidies in Nigeria) but there is nothing in the programme to generate social and economic justice and create inclusive communities for the good of all. This is the speed lane for the escalation of poverty, unemployment, exploitation, inequality and insecurity. Inevitably, we have to transcend the madness of free-market fundamentalism and give a rightful place to God, ethics and justice.

Three egalitarian thinkers Henry George, R. H. Tawney 
and John Rawls, show us that fairness and justice are not nice-to-have adjuncts to social relationships, but fundamental requisites of well-being and happiness, integral to a sustainable, durable social order of security and development. They insist that society should be built on principles that ensure access for everyone to key primary goods, to a reasonable income and material well-being, to opportunity and basic rights and liberties, which allow all citizens to feel they have been given a proper chance to be full members of the society. Their clarion call is not for utopian collectivism. We do not all have to earn the same wage, live in the same sort of house, eat the same food, wear the same clothes, drive the same kind of car. The clarion call is just for less inequality, for more fairness and justice. This their view of society is so convincing that it is hard to think of a reason - other than selfish greed - for anyone to argue with them. For instance, in a particular country, some Secondary School Certificate holders are privileged to serve the government and are paid over $\$ 20$ million per month, whereas the same country finds it difficult to pay all unemployed graduates $\$ 18,000$ per month. For how long shall we continue in greed, selfishness, miasma of corruption and abuse of office before we can allow everyone a stake in society?

In 2011, Elumelu [2, founder of the Tony Elumelu Foundation (TEF) called on entrepreneurs and business leaders on the African continent, to embrace the concept of "Africapitalism". He added that the much needed growth and development of Africa can best be achieved through AFRICAPITALISM - a private sector conscious commitment to the economic transformation of Africa through investments that generate economic and social wealth for the economic wellbeing of Africans and common good of all.

\section{Build an "Economy of Communion"}

The "Economy of Communion" founded in 1991 by Chiara Lubich, is one of the great works of the Focolare Movement. The Economy of Communion or of sharing, is a product of the "culture of giving of the Gospel put into practice" in economic activities. Its entrepreneurs are asked to use their skills and creativity to produce useful, quality products, and to run their businesses honestly, without damaging the environment or being drawn into unethical forms of competition. They are asked to divide future profits into three ways:

- One part to be kept to cover current costs and the future development of the business.

- One part to be given to the poor to lift them out of the vicious cycle of poverty, so that they also are able to contribute to the community.

- The final part to finance education.

This economy is based on a commitment to grow together but not the capitalist economy of survival of, or wealth for the fittest. Economy of communion involves risking money, and sharing inventiveness and talents, within a culture of giving. It is a transparent economy that offers a suitable and realistic alternative for the prevailing precarious global economic shockwaves. Despite the extreme negative perception and rating by many observers in 1991, the "Economy of Communion" has gone from strength to strength, as a viable alternative to the economy of greed and individualism. Mofid[4].confirms that there are now more than 750 such businesses in Brazil, the Philippines, Italy, Germany and elsewhere and more businesses are being developed each year in different countries. Jorge Braga de Macedo, referred to the "Economy of Communion" as an "important proposal for economists, working for development in the world's poorest nations". It has succeeded in encouraging a new human model, one which finds fulfillment in relationships rather than in self-promotion and clamour for being "The Richest Man in the World". The concept of the richest man in the world is an anathema and should be discouraged and abolished all over the world. It heightens economic injustice, exploitation and primitive accumulation by a few, at the detriment of othersthe majority. "Economy of Communion" is capable of eradicating "corporate greed and exploitation", and eventual end of "Occupy the Wall Street Movement" all over the world.

The Focolare Movement, the Economy of Communion and its associated businesses, are true examples of socially acceptable commerce, conducted according to Catholic social teaching, where love, justice, and solidarity to the common good, are the main driving forces. This realization reminds us that our spiritual consciousness and righteousness before God, depends largely on how we treat the needy and vulnerable. Those who consider themselves True Believers in God should not forget this message. All religions of the world are rooted on the common good for all. For instance, the Christians, Jeremiah 5:27-29, speaks strongly against the greed of the people.

- Deuteronomy 24: 19-21 exhorts us to share our goods,

- Matthew 25:31-36 contains Jesus' description of the last-judgement.

- Acts of tile Apostles 2:42-47 summarized the life of the early Christians, thus:

"They devoted themselves to the teaching of the apostles and to the communal life, to the breaking of the bread and to the prayers. Awe came upon everyone, and many wonders and signs were done through the apostles. All who believed were together and had all things in common; they would sell their property and possessions and divide them among all, according to each one's need. Every day, they devoted themselves to meeting together in the temple area and to breaking bread in their homes. They ate their meals with exultation and sincerity of heart praising God and enjoying favour with all the people. And every day, the Lord added to their number those who were being saved", Furthermore, in Acts of Apostles 4:33-35. "The community of believers was 
of one heart and mind, and no one claimed that any of his possessions was his own, but they had everything in common. With great power, the apostles bore witness to the resurrection of the Lord Jesus, and great favour was accorded them all. There was no needy person among them for those who owned property or houses would sell them: bring the proceeds of the sale, and put them at the feet of the apostles, and they were distributed to each according to need".

The first disciples gave to others what they needed. Their community provides a model for sharing material possessions, so that those in need are provided for. Their spirit of generosity and worship should be embraced by all Christians globally. In so doing, they would surely attract followers to the Way of the Lord Jesus, while serving the needy throughout the world "according to each one's need".

Why are the Christians of today not living communal life as stated here'? One family or two takes everything home as their private inheritance. What do we have today globally? Church owners and founders, rapidly establishing branches, and building Schools-Day-Care, Nursery, Primary, Secondary and Universities. Some are even proud to announce that they have built eight well-equipped private Universities: built with the sweat and blood of helpless and impoverished church members, and still milking them dry to abject poverty. Worse still, majority of the church members may not have the financial capacity to train even one child in such universities. Where is the communal life of the early Christians? Where is the original concept of missionary schools introduced by the early missionaries for church members?

There is an idea of common good in all religions of the world: the words in their Sacred and Holy Books are very clear on this subject. Human greed coupled with technological progress, has led to the increasing commercialization of work and "merchandizing of the souls of men", so that it is now devoid of any spirituality.

\section{Conclusions}

Ultimately, the economy is far too important to be left to those who deal in abstractions, and the society is too valuable to be placed at the service of the competitive market. In the words of Upton Sinclair, "It is difficult to get a man to understand something, when his salary depends upon, his not understanding it'. Mofid [5] states that it is only by empowering others to share with you, that one can empower oneself to share with others by empowering others to teach you, you empower yourself to teach others. There is a "common good" in all of us and in all religions of the world.

The centuries-old wisdom of the Persian Poet, Sadi, summaries this paper thus: The children of Adam are limbs of one another in terms of creation, they are of the selfsame essence. He further expatiated his views thus: Human beings are like parts of a body, created from the same essence.
When one part is hurt and in pain the others cannot remain in peace and be quiet. He concluded that if the misery of others leaves you indifferent and with no feelings of sorrow you cannot be called a human being (Sadi-Persian Poet).

As a Professor of Moral Philosophy at Glasgow University, Adams Smith wrote in his book: "The Theory of Moral Sentiments" that "No society can surely be flourishing and happy of which the greater part are poor and miserable "(Adam Smith in Mofid [4].

\section{Recommendations}

The world cannot come out of these prevailing and recycling problems, with the same thinking that instituted the problems in the first place. There is need for a paradigm shift in our mind-set globally. We therefore, recommend as follows:

- Ethics- and Economic Justice-based Capitalism should be promoted, in order to enhance global socio-economic stability, peace and sustainable development for the common good of all. This entails that the curricula of Business Schools, Universities and other Higher Institutions, must contain both the doctrines of capitalist ideology and true human values of morality and spirituality, for the world to enjoy global peace, security and sustainable development.

- Everyone should be seen to be a stakeholder in the society through the reduction of poverty, unemployment, inequity/economic injustice, exclusion and exploitation- the root cause of insecurity globally. This is not just a clarion call for less inequality but also, for more fairness and economic justice for the ultimate good of all.

- Economy of Communion should be adopted by all religions of the world as a way of life. "Economy of Communion" is established and adopted, one would be inclined to believe, that it will go a long way in eradicating "Corporate Greed" and exploitation, which will culminate into discouraging the likes of "Occupy the Wall Street Movement" that keeps reverberating all over the world.

- For socio-economic development to be feasible and sustainable, the prevailing globalised culture needs, the re-awakening of human spirit of love, compassion, conscience, morality, ethics and spirituality. Mofid [4], argued that, it is only by bringing together the beliefs within the religions of the world and applying them to economic system, that we can create all-inclusive world for the good of all.

- The concept of the "Richest Man in the World" should be abolished forthwith-nationally, regionally, continentally and globally. Rather, the world's most successful financiers/businessmen cum super-rich, should be rated based on the number of human beings they have liberated from poverty and ignorance through education (Scholarships) and/or empowered through 
technical skills acquisition (Human capital development) - (for instance, if one globally acclaimed Super-Rich should liberate and empower at least 100 million human beings or more, in a year, then, the world will rise and celebrate him, as the GREATEST for that year). That should be the appropriate and humanistic rating for the richest man in the world and not greed-motivated and selfish economic growth, corporate bottom-line, and the pursuit of self-interest. If and only if, the competition is tailored towards this direction, then, their primitive accumulation will become more meaningful contribution to humanity and to the creator.

\section{REFERENCES}

[1] Elumelu, T. (2011) "Building a Pan-African Business", Paper Presented at Strathmore Business School, Kenya, East Africa, in Tell Weekly Magazine, No 35, September 5, P.55. http://www.commondreams.org.

[2] Englama, A. \& Bamidele, A (1997) Measurement Issue in Poverty Alleviation in Nigeria, Selected Papers for the 1997 Annual Conference of the Nigerian Economic Society (NES).
[3] Francis, O. E. (2007). Corruption versus Sustainable Development in Nigeria: Any Resolution in sight? In H. O. Agwuarna, (ed) Contemporary Issues and the Challenges of Sustainable Development in New Millennium. Nigerian Experience, Ibadan, Heinemann.

[4] Mofid, K (2002) Globalization for the Common Good Initiative, United Kingdom, www.gcgi.info.

[5] Mofid, K. and Lum, J. (2006) Globalization, and Identity: Cultural Diversity, Religion and Citizenship, Toda: Institute for Global Peace and Policy Research.

[6] Revallion, M \& Bidani, B (1994) "How Robust is a Poverty Profile" The World Bank Economic Review, 8 (10) January.

[7] Soludo, C. C. (2007). The Nigerian Economy: can we achieve vision 20-2020: Abuja, Central Bank of Nigeria.

[8] UNESCO (2004), African Development Report of 2003: Africa in the World Economy. Geneva.

[9] United Nations (1987)' Report of The World Commission on Environment, General Assembly Resolution, 421187, December,11,(1987).

[10] Uniamikigho. O. (1997) Poverty Alleviation under Nigeria. A paper presented at the Annual Conference of Nigerian Economic Society. Abuja.

[11] World Bank (1902). Poverty and Welfare in Nigeria. Geneva World Bank Report. 